\title{
Hemokromatose - fra underdiagnostisert kuriositet til folkesykdom
}

\begin{abstract}
Sammendrag
Bakgrunn. Hemokromatose er en hyppig lidelse som med tidlig diagnose og riktig behandling har svært god prognose. Hensikten med artikkelen er å gi oppdatert informasjon om hemokromatose med særlig vekt på patobiokjemi, praktisk diagnostikk og behandling.
\end{abstract}

Materiale og metode. Grunnlaget for artikkelen er et ikke-systematisert litteraturs $ø$ k i ulike databaser med et skjønnsmessig utvalg av artikler basert på forfatternes kompetanse og erfaring.

Resultater. Arvelig hemokromatose er en autosomalt recessiv tilstand karakterisert av jernoverskudd som følge av mangeårig økt absorpsjon av jern i tarmen. I praksis er det ofte tilfeldig oppdaget høy transferrinmetning og/eller plasma-ferritin som gir mistanke om hemokromatose. De tidlige symptomer er asteni og leddsmerter. Ca. $85 \%$ av pasientene med arvelig hemokromatose er homozygote for mutasjonen C282Y i HFE-genet, men de fleste homozygote forblir asymptomatiske. Behandlingen er årelating ved plasmaferritin > $500 \mu \mathrm{g} / \mathrm{l}$, både ved arvelig hemokromatose og ved jernoverskudd av ukjent årsak.

Fortolkning. De biokjemiske mekanismene bak hemokromatose er ikke fullstendig klarlagt, men det synes klart at det leverproduserte proteinet hepcidin spiller en nøkkelrolle i patogenesen. Jernoverskudd kan også være sekundært til annen sykdom, som $\beta$-talassemi og andre tilstander som krever hyppige blodtransfusjoner over lang tid. Behandlingsmålet er å holde plasma-ferritin i størrelsesorden $20-50 \mu \mathrm{g} / \mathrm{l}$.

\section{Tor-Arne Hagve}

tor.arne.hagve@ahus.no

Avdeling for medisinsk biokjemi

Rikshospitalet

Fakultetsdivisjon Akershus universitetssykehus, Lørenskog

1487 Lørenskog

\section{Arne Åsberg}

Avdeling for medisinsk biokjemi

St. Olavs hospital

\section{Rune Ulvik}

Institutt for indremedisin

Universitetet i Bergen

og

Laboratorium for klinisk biokjemi

Haukeland universitetssykehus

\section{Berit Borch-lohnsen}

Avdeling for ernæringsvitenskap Institutt for medisinske basalfag Universitetet i Oslo

\section{Ketil Thorstensen}

Avdeling for medisinsk biokjemi

St. Olavs hospital

I 1979 ble det i The Lancet (1) publisert en historie om en flypassasjer som utløste alarmen i sikkerhetskontrollen uten at det var mulig å finne årsaken der og da. Det viste seg å være en pasient med et betydelig jernoverskudd (20 ganger det normale) forårsaket av hyppige blodtransfusjoner. Historien sier oss at store mengder jern kan lagres i kroppen, hvilket kan ha alvorlige konsekvenser, ikke bare for flyreiser. Jernoverskudd er et resultat av at tilførselen av jern har overskredet jernbehovet. En rekke ulike forhold kan være årsak, hvorav arvelig hemokromatose er langt den hyppigste. Jernoverskuddet kan imidlertid også være sekundært til annen sykdom. De hyppigste årsaker til sekundær hemokromatose er $\beta$-talassemi, sideroblastanemi, hemolytiske anemier, kronisk hepatitt $\mathrm{C}$, alkoholisk siderose, porphyria cutanea tarda, metabolsk syndrom samt alle tilstander som krever hyppige blodtransfusjoner over lang tid. Begrepet «hemokromatose» brukes ofte som en betegnelse på jernoverskudd generelt, mens det $\mathrm{i}$ dagligtale brukes synonymt med arvelig hemokromatose. Det pågår en diskusjon om hvorvidt «arvelig hemokromatose» skal inkludere pasienter som har genetisk disposisjon uten symptomer eller kliniske funn samt pasienter som har påviselig jernoverskudd med symptomer og ikke påviselig genetisk disposisjon. I det følgende brukes ordet «hemokromatose» for jernoverskudd, både primær og sekundær, mens den primære formen spesifiseres som «arvelig hemokromatose».

\section{Materiale og metode}

Grunnlaget for artikkelen er et ikke-systematisert litteratursøk i ulike litteraturdatabaser med et skjønnsmessig utvalg av artikler basert på forfatternes kompetanse og erfaring innen feltet. Flere av forfatterne har deltatt $\mathrm{i}$ forskning innen jernstoffskiftet $\mathrm{i}$ flere tiår.

\section{Arvelig hemokromatose - en arv fra vikingene?}

Arvelig hemokromatose har vist seg å forkomme betydelig hyppigere enn tidligere antatt, noe som skyldes enklere og bedre diagnostiske hjelpemidler og økende bevissthet blant leger om betydningen av tidlig diagnose. Den høye hyppigheten i Skandinavia og i England/Irland/Skottland er bakgrunnen for flere teorier om opprinnelsen til arvelig hemokromatose. Det er estimert at tidspunktet for den genetiske forandringen (mutasjonen) ligger 1 000-6 000 år tilbake i tid (2). En mulig hypotese er at mutasjonen oppsto $\mathrm{i}$ den keltiske folkegruppen (Mellom-Europa), mens kartlegging av utbredelsen antyder at mutasjonen oppsto på vestlandet i Norge og spredte seg med vikingenes utflukter til England, Island, Færøyene, Grønland og Europa for øvrig $(2,3)$. Det er postulert at arvelig hemokromatose beskyttet mot jernmangel, ikke minst hos gravide og fødende kvinner, samt i forbindelse med overgang fra jakthusholdning med mye kjøtt og til korndyrking med mindre og dårligere tilgjengelighet av jern i kosten (3). Det kliniske bildet ved hemokromatose ble første gang beskrevet i 1865 (4), men det tok 25 år før jernets betydning som patogenetisk faktor ble påvist og begrepet «hemokromatose» ble introdusert (5). Det tok ytterligere 45 år før

\section{Hovedbudskap}

- Arvelig hemokromatose har en hyppighet på $0,7 \%$ i den norske befolkningen

- Tidlige symptomer er asteni og artralgi

- Diagnosen baseres på høy plasmaferritinverdi, høy plasma-transferrinmetning og mutasjonen $\mathrm{C} 282 \mathrm{Y} / \mathrm{C} 282 \mathrm{Y}$ i HFE-genet

- Behandles med årelating ved plasmaferritin over $500 \mu \mathrm{g} / \mathrm{l}$ 


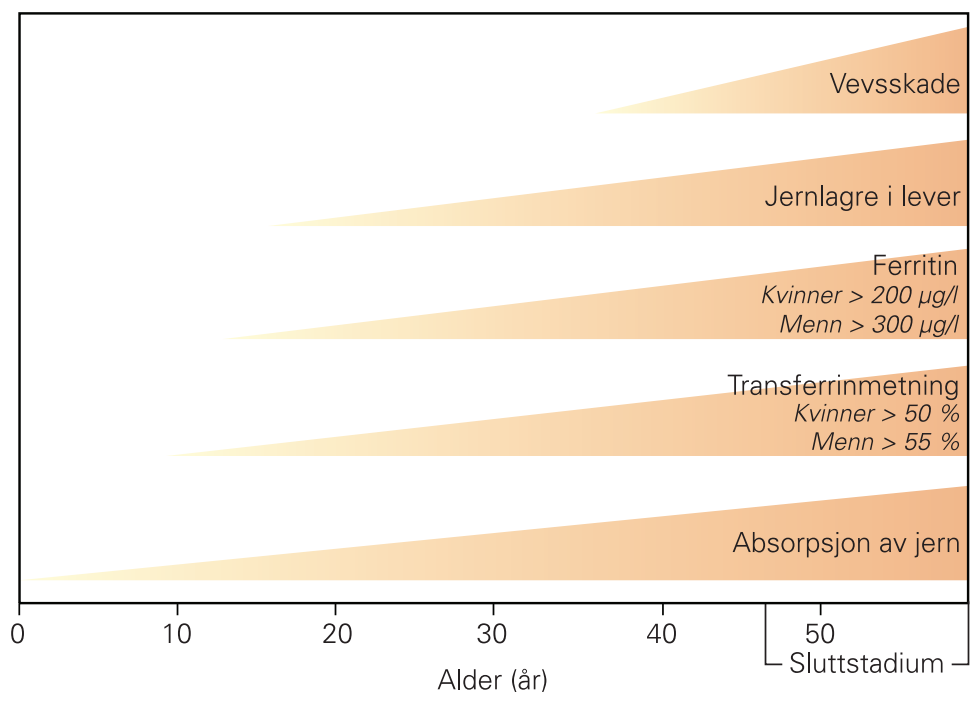

Figur 1 Oversikt over endring i jernvariabler og jernavleiring i forløpet av ubehandlet arvelig hemokromatose. For noen variabler er det angitt grenseverdier som skal gi mistanke om hemokromatose og føre til videre utredning

sykdommen ble foreslått å være arvelig (6), og det var først i 1975 at dens arvelige natur ble påvist (7). Etter at Feder og medarbeidere (8) i 1996 viste at de fleste pasienter med arvelig hemokromatose er homozygote for en spesifikk mutasjon i $H F E$-genet, er gentester tatt i bruk i rutinemessig diagnostikk av hemokromatose.

\section{Genetikk}

Arvelig hemokromatose er en av de hyppigste genetiske tilstander i Norge, og den genetiske disposisjonen er i dag vel kjent. I HFEgenet på kromosom 6, ble det i 1996 påvist en mutasjon - som oftest betegnet C282Y hos personer med arvelig hemokromatose (8). En annen mutasjon i det samme genet betegnet H63D - finnes også relativt hyppig hos pasienter med arvelig hemokromatose, men da kun i dobbelt heterozygoti med C282Y (compound heterozygot). Arvelig hemokromatose er særlig utbredt i NordEuropa og finnes knapt i Afrika og Asia. I Norge er ca. $7 \%$ av befolkningen homozygote for C282Y-mutasjonen, mens $12-15 \%$ er bærere (heterozygote). Allelfrekvensen, dvs. forekomsten av mutasjonen i hele befolkningen, for C282Y-mutasjonen er i Danmark 5,7\%, Finland 3,7\%, Island 5,1\%, Norge $6,6 \%$ og Sverige 5,2\%. Høyest frekvens finnes i Irland, med 9,7\%, mens andre europeiske land har allelfrekvenser i størrelsesorden 1-4\% (3). Allelfrekvensen for H63D-mutasjonen er vesentlig høyere. I en norsk undersøkelse av 505 friske sykehusansatte fant Distante og medarbeidere (9) at $1,4 \%$ var homozygote og $18 \%$ var heterozygote for H63D-mutasjonen. Dette gir en allelfrekvens på $11,5 \%$.

I helseundersøkelsen i Nord-Trøndelag i 1995-97 (HUNT2) ble det funnet at ca.
$85 \%$ av dem med sikkert påvist arvelig hemokromatose var homozygote for C282Ymutasjonen, mens ca. $5 \%$ var heterozygote for både C282Y- og H63D-mutasjonene (10). Andre studier har konkludert med at $1-2 \%$ av dobbelt heterozygote er disponert for å utvikle arvelig hemokromatose (11) Distante og medarbeideres undersøkelse viste også at verken H63D hetero- eller homozygote hadde forhøyede verdier for plasma-ferritin eller plasma-transferrinmetning sammenliknet med dem som ikke hadde noen mutasjoner i HFE-genet (9).

\section{Patobiokjemi}

Kroppen har ingen kjente mekanismer som regulerer jernutskillingen, og kroppens innhold av jern er derfor kun regulert av absorpsjonen av jern fra kosten og opptaket i øvre del av tynntarmen.

Selv om de fleste intracellulære transportproteiner og reseptorer i både tarmceller og andre celler nå sannsynligvis er kjent, er koblingen mellom kroppens jernbehov og reguleringen av jernopptak ikke helt klarlagt. For å opprettholde jernhomøostase må det finnes en regulert signaloverføring mellom celler som absorberer jern (enterocytter), celler som forbruker jern (erytroide forstadier) og celler som lagrer jern (leverceller og makrofager). I denne sammenhengen spiller det hormonliknende peptidet hepcidin en nøkkelrolle i normal jernhomøostase og i patogenesen ved utvikling av hemokromatose $(12,13)$.

HFE-proteinet er en enkel proteinkjede med stor likhet med MHC klasse I-proteiner. Det uttrykkes i de fleste celler, og i leveren inngår HFE-proteinet $i$ hepatocyttenes apparat for registrering av plasma-transferrinmetning. Når plasma-transferrinmetning øker som uttrykk for økt jernmengde i blodet, vil hepatocyttene oppregulere produksjon og frisetting av hepcidin. Hevet hepcidinnivå gir nedregulering av transporten (eksport) av jern fra tarmceller (og makrofager) til blodbanen. Ved arvelig hemokromatose, som skyldes mutasjon i $H F E$-genet, vil mangel på funksjonelt HFE-protein forhindre oppregulering av hepcidinproduksjonen, slik at transporten av jern fra tarmceller til blodbanen ikke blir tilstrekkelig nedregulert. Resultatet blir et jernopptak som er for høyt $i$ forhold til den jernmengden som er i kroppen. For en detaljert beskrivelse av disse mekanismene vises det til en annen artikkel i dette nummer av Tidsskriftet (14).

Det patologisk økte jernopptak i tarmen kan være i størrelsesorden 1-3 mg utover det daglige behovet. Dette medfører en akkumulering på eksempelvis $20-30 \mathrm{~g}$ jern (normalt er det totalt 3-4 g jern i kroppen) i løpet av 40 år.

Det er ikke klarlagt hvorfor ca. $10 \%$ av pasientene med arvelig hemokromatose, vurdert ut fra kliniske funn og påviselig jernoverskudd, ikke har de aktuelle mutasjoner, eller hvorfor noen personer har C282Y-mutasjonen uten at det kan påvises jernoverskudd (15). Dette viser imidlertid at det må finnes andre genetiske faktorer som også påvirker utviklingen av arvelig hemokromatose. Slike faktorer kan være for eksempel HLA-type $(7,16)$, antall av og forhold mellom T-lymfocytt undergrupper (17) eller det nylig beskrevne beinmorfogeneseproteinet, BMP (bonemorphogenetic protein) (18).

\section{Hvorfor er $ø$ kt mengde jern i kroppen farlig?}

Ved jernoverskudd øker den intracellulære konsentrasjonen av redoksreaktivt jern, en viktig faktor ved danning av toksiske oksygenradikaler. Disse gir peroksidasjon av lipider og skade i organeller og cellemembraner. Dette medfører celledød og vevsskade i lever (fibrose med påfølgende cirrhose) og myokard (fibrose og kardiomyopati), samt i endokrine organer hvor det typiske eksemplet er fibrose i pancreas med utvikling av diabetes.

\section{Kliniske symptomer og diagnose}

Symptomene varierer fra pasient til pasient, hovedsakelig fordi mutasjonen har lav penetrans og fordi diagnosen stilles på forskjellig stadium i sykdomsutviklingen. Sykdommen utvikler seg langsomt, men vil ubehandlet kunne resultere i irreversible og dødelige skader i ulike organer, særlig i lever og hjerte. Hos kvinner vil sykdomsutviklingen være langsommere enn hos menn, fordi blodtap ved menstruasjon (opptil 1,8 mg/døgn) bremser jernopphopningen.

Lærebokbeskrivelsen av hemokromatose (19) med diabetes (fibrose i pancreas) og brun hud (økt antall melanocytter) som sammen ble beskrevet som bronsediabetes, ses sjelden i dag. Likeledes er levercirrhose og 
hjerteaffeksjon sjeldent. I en stor screeningundersøkelse (HUNT) av mer enn 65000 individer der $0,68 \%$ var homozygote for C282Y-mutasjonen, var det bare fire personer som hadde levercirrhose (10). I dag stilles diagnosen ofte ved tilfeldige legeundersøkelser hvor pasientens jernstoffskifte kartlegges, eller ved undersøkelse av slektninger av personer med kjent hemokromatose. Etter hvert som diagnosen stilles tidligere, er symptomer ofte begrenset til asteni og leddsmerter samt potensproblemer hos menn (20).

Mistanke om hemokromatose baserer seg gjerne på tilfeldig påvist høy transferrinmetning og/eller ferritinkonsentrasjon, eller på de tre a-er: asteni, artralgi og økt ALAT.

Figur 1 viser endringene i biokjemiske variabler i utviklingsforløpet av arvelig hemokromatose. Det patologisk økte jernopptaket starter hos noen individer sannsynligvis allerede i småbarnsalder, mens det hos andre skjer senere. En varig, patologisk økt plasmatransferrinmetning skal uansett alder gi mistanke om hemokromatose. Høy plasma-ferritinkonsentrasjon som følge av jernoverskudd kommer ofte senere $\mathrm{i}$ tenårene etter avsluttet vekst.

Plasma-transferrinmetning vil slå ut tidlig med økt verdi. For alle menn med verdier $>55 \%$ og for kvinner med verdier $>50 \%$, som holder seg over tid, bør det gjøres videre utredning med tanke på hemokromatose. Transferrinmetningen kan være betydelig forhøyet allerede i barnealder. Verdi på $80 \%$ er funnet hos en sjuåring (Rune J. Ulvik, personlig meddelelse). En samtidig høy plasma-ferritinverdi styrker diagnosen. Plasmaferritinverdien øker i hele forløpet, men kan være vanskelig å tolke fordi andre faktorer påvirker nivået (betennelsestilstander, akuttfasereaksjoner, levercellenekrose, kreftsykdom, alkoholmisbruk). Det er også et problem at ulike sykehus har ulike metoder for bestemmelse av plasma-ferritin og dermed også ulike referansegrenser. Referanseområdet øker noe med alder, særlig hos kvinner etter menopause. Anbefalingen er at alle menn med plasma-ferritin $>300 \mu \mathrm{g} / \mathrm{l}$ og kvinner med verdier $>200 \mu \mathrm{g} / \mathrm{l}$ over lengre tid skal utredes med mistanke om jernoverskudd. Plasma-ferritin kan ved hemokromatose ha verdier på flere tusen $\mu \mathrm{g} / 1$.

Når det er påvist varig høy plasma-transferrinmetning og høy plasma-ferritinkonsentrasjon, er gentest neste steg i utredningen, med påvisning av de karakteristiske mutasjoner i HFE-genet. Før gentest var tilgjengelig, ble det ofte utført leverbiopsi for påvisning av jern i hepatocyttene. Gentesten har i stor grad gjort leverbiopsi overflødig, bortsett fra hos de i størrelsesorden $10 \%$ av pasientene som har kliniske funn og jernvariabler forenlig med hemokromatose, men uten mutasjoner i $H F E$-genet.

Det er i store materialer funnet at hos middelaldrende menn med nyoppdaget homozygoti for C282Y-mutasjonen har ca. $4 \%$ levercirrhose og ca. $11 \%$ fibrose (21). I Nor- ge er $4 \%$ av alle tilfeller med levercirrhose forårsaket av hemokromatose (22). Flere studier viser at pasienter med homozygot C282Y-mutasjon og plasma-ferritin $<1000$ $\mu \mathrm{g} / \mathrm{l}$ med liten sannsynlighet har cirrhose (23-25). Det konkluderes med at det ikke er nødvendig å foreta leverbiopsi på pasienter med plasma-ferritin $<1000 \mu \mathrm{g} / \mathrm{l}$, men dette må ses i sammenheng med pasientens alder, nivå av leverenzymer og en grundig klinisk undersøkelse. Leverbiopsi har altså $i$ dag en betydelig mindre rolle i diagnostikk av hemokromatose enn tidligere, men har en prognostisk betydning for eventuell påvisning av irreversible skader i leveren. Ikke minst kan dette være viktig fordi pasienter med cirrhose har økt risiko for å få levercellekreft. Det er vist at C282Y-homozygote menn har en risiko i størrelsesorden $2 \%$ for å få hepatocellulært karsinom (26). I en annen studie ble det vist at hos menn med arvelig hemokromatose og påvist levercirrhose fikk 19 av 142 levercellekreft (27). Andre årsaker til høy plasma-ferritin og eventuell leversykdom må utelukkes, for eksempel hemoglobinopatier, sideroblastanemi, myelodysplastisk syndrom, alkoholmisbruk, metabolsk syndrom, hepatitt og hyppige blodoverføringer.

\section{Behandling}

Behandlingen er i all sin enkelthet venesectio (årelating). Det er ingen formell konsensus for når venesectio skal startes, verken ved arvelig hemokromatose eller ved jernoverskudd av andre årsaker. Det er hevdet at pasienter med homozygot C282Y-mutasjon skal behandles allerede ved plasma-ferritin $>300 \mu \mathrm{g} / \mathrm{l}$ hos menn og $>200 \mu \mathrm{g} / \mathrm{l}$ hos kvinner (28), mens andre hevder at behandling kan vente til plasma-ferritin $>1000 \mu \mathrm{g} / \mathrm{l}$. Jo senere i forløpet behandlingen starter, jo flere årelatinger må utføres, hvilket øker både belastningen for pasienten og gir økte økonomiske kostnader. I praksis er det sannsynligvis riktig å starte årelating når plasmaferritin er i størrelsesorden $500 \mu \mathrm{g} / \mathrm{l}$. Det er ingen uvanlig problemstilling at pasienten har høy plasma-ferritinverdi ved gjentatte kontroller over tid uten at de har mutasjoner relatert til arvelig hemokromatose, og hvor andre årsaker til den høye verdien er eliminert (alkoholmisbruk, hepatitt (virus, autoimmun), hematologiske sykdommer, kroniske betennelsestilstander). Også i disse tilfellene er det riktig å starte behandling med venesectio ved plasma-ferritin $>500 \mu \mathrm{g} / 1$ (29).

Det anbefales å tappe 4-500 $\mathrm{ml}$ blod hver gang med en hyppighet som er avhengig av ferritinnivået. Initialt kan det være aktuelt med tapping så hyppig som hver uke. Hyppigheten må alltid vurderes i forhold til hemoglobinnivået. Målet med tappingene er å få plasma-ferritinkonsentrasjonen ned i området $20-50 \mu \mathrm{g} / 1$, som så skal bibeholdes (30). Som vedlikeholdsbehandling er det ofte nok med tapping 3-4 ganger årlig.
I noen få tilfeller når venesectio ikke kan gjennomføres, kan det være aktuelt med jernkelerende behandling. Medikamentell behandling gis ikke i tillegg til årelating.

Kostholdsrelaterte tiltak har lite for seg, bortsett fra at det anbefales at pasienter med arvelig hemokromatose ikke skal ha tilskudd av vitamin C (som stimulerer opptaket av jern i tarm).

Prognose og effekt av behandling er avhengig av graden av jernoverskudd. Ved vellykket behandling kan kardiale plager bli bedre og insulinbehovet reduseres, mens ar-

\section{Ramme 1}

\section{Norsk kompetansegruppe} for hemokromatose og andre sykdommer i jernstoffskiftet

Det har i en årrekke eksistert en uformell kompetansegruppe for hemokromatose bestående av kolleger med spesiell faglig interesse for sykdomsgruppen, med representanter fra de medisinske spesialitetene medisinsk biokjemi, gastroenterologi, immunologi og transfusjonsmedisin samt hematologi. Flere har vært involvert i formelle «hemokromatosepoliklinikker». Interessegruppen har hatt tett samarbeid med pasientorganisasjonen Norsk Hemokromatoseforbund

(www.hemokromatose.no).

Interessegruppen er nylig formelt etablert som «Norsk kompetansegruppe for hemokromatose og andre sykdommer i jernstoffskiftet», med følgende formål:

- Sørge for kontakt og samarbeid mellom fagmiljøene i Norge som arbeider med sykdommer i jernstoffskiftet

- Formidle kunnskap til norsk helsevesen, allmenheten, myndigheter og pasientorganisasjoner

- Fremme interesse for forskning innen jernstoffskiftet

- Arbeide for kontakt med tilsvarende grupper $\mathrm{i}$ andre land

Ved behov for råd og informasjon om hemokromatose og for henvisning av pasienter til diagnose, behandling og oppfølging kan følgende kontaktes: Nord-Norge: Medisinsk avdeling v/Ann Ragnhild Broderstad, Universitetssykehuset Nord-Norge, Harstad sykehus (Tlf. 770150 00)

Midt-Norge: Medisinsk avdeling v/Kristian Hveem, Innherred sykehus, Levanger (Tlf. 740980 00)

Vest-Norge: Hemokromatosepoliklinikk v/Rune J. Ulvik, Hematologisk seksjon, Avdeling for indremedisin, Haukeland universitetssykehus (Tlf. 559731 00) Sør- og Øst-Norge: Hemokromatosepoliklinikken v/Lars Mørkrid, Avdeling for medisinsk biokjemi, Rikshospitalet, (TIf. 230710 75) og Tor-Arne Hagve, Laboratoriemedisinsk senter, Akershus universitetssykehus (TIf. 679696 50) 
tropati og gonadale symptomer påvirkes lite. Hos velbehandlede pasienter uten levercirrhose er livslengden den samme som hos normalbefolkningen. Dette understreker igjen nødvendigheten av tidlig diagnose.

Undersøkelse av nære slektninger (søsken og barn) til pasienter med påvist arvelig hemokromatose er viktig for at eventuell behandling kan startes så raskt som mulig.

Når det gjelder screening av større befolkningsgrupper, er det studier som tyder på at screening av yngre menn for arvelig hemokromatose er nyttig og kostnadseffektivt (31). Det er imidlertid et problem at det er umulig å forutsi hvilke screeningpositive personer som ubehandlet får alvorlig sykdom. I USA anbefales det at man ikke screener for arvelig hemokromatose $\mathrm{i}$ en frisk, asymptomatisk populasjon (32). Det er for tidlig å ta stilling til om screening er nyttig og kostnadseffektivt.

\section{Norsk kompetansegruppe}

Ytterligere informasjon kan fås ved henvendelse til kontaktpersoner tilknyttet Norsk kompetansegruppe for hemokromatose og andre sykdommer i jernstoffskiftet (ramme 1).

\section{Oppgitte interessekonflikter: Ingen}

\section{Litteratur}

1. Jim RT. Unusual test for iron overload. Lancet 1979; 2: 1028

2. Milman N, Pedersen P. Evidence that the Cys282Tyr mutation of the HFE gene originated from a population in Southern Scandinavia and spread with the Vikings. Clin Genet 2003; 64 : $36-47$

3. Distante S, Robson KJ, Graham-Campbell J et al. The origin and spread of the HFE-C282Y haemochromatosis mutation. Hum Genet 2004; 115 . 269-79

4. Trousseau A. Glycosurie, diabète sucré. Clinique Médicale de l'Hotel-Dieu de Paris. Paris: Baillière 1865: $663-98$.
5. von Recklinghausen FD. Über hämochromatose. Tagbl Versamml Natur Ärtze Heidelberg 1889; 62: 324-5.

6. Sheldon JH. Haemochromatosis. London: Oxford University Press, 1935

7. Simon M, Pawlotsky Y, Bourel M et al. Hémochromatose idiopathique: maladie associée a l'antigéne tissulaire HLA 3. Nouv Presse Méd 1975; 19: 1432.

8. Feder JN, Gnirke A, Thomas W et al. A novel MHC class-I-like gene is mutated in patients with hereditary hemochromatosis. Nat Genet 1996 14: $399-408$.

9. Distante S, Berg JP, Lande K et al. High prevalence of the hemochromatosis-associated Cys282Tyr HFE gene mutation in a healthy Norwegian population in the city of Oslo, and its phenotypic expression. Scand J Gastroenterol 1999; 34; $529-54$

10. Åsberg A, Hveem K, Thorstensen K et al. Screening for hemochromatosis: high prevalence and low morbidity in an unselected population of 65,238 persons. Scand J Gastroenterol 2001; 36: 1108-15.

11. Pietrangelo A. Hereditary hemochromatosis. Biochim Biophys Acta 2006; 1763; 700-10

12. Swinkels DW, Janssen MCH, Bergmans J et al. Hereditary hemochromatosis: genetic complexity and new diagnostic approaches. Clin Chem 2006. 52: $950-68$.

13. Kemna E, Tjalsma H, Laarakkers $C$ et al. Novel urine hepcidine assay by mass spectrometry. Blood 2005; 106: 3268-70.

14. Borch-lohnsen B, Hagve T-A, Hauge A et al. Regulering av jernbalansen. Tidsskr Nor Legeforen 2009; 129: 858-62.

15. Åsberg A, Hveem K, Krüger 0 et al. Persons with screening-detected hemochromatosis: as healthy as the general population? Scand J Gastroenterol 2002; 31: 719-24.

16. Olsson KS, Ritter B, Hansson N et al. The HLA-A1B8 haplotype hitchhiking with the hemochromatosis mutation: does it affect the phenotype? Eur J Haematol 2007; 79: 429-34.

17. Porto G, Cardoso C, Gordeuk V et al. Clinical and genetic heterogeneity in hereditary haemochromatosis: association between lymphocyte counts and expression of iron overload. Eur J Haematol 2001; 67: 110-8.

18. Lin L, Valore EV, Nemeth E et al. Iron transferrin regulates hepcidin synthesis in primary hepatocyte culture through hemojuvelin and BMP2/4. Am J Hum Genet 2007; 81: 799-807.

19. Adams P. Brissot P. Powell LW. EASL International Concensus Conference on Haemochromatosis. J Hepatol 2000; 33: 485-504.
20. Pietrangelo A. Hereditary hemochromatosis a new look at an old disease. N Engl J Med 2004; 350: 2383-97.

21. Åsberg A, Hveem K, Halvorsen T et al. Prevalence of liver fibrosis and cirrhosis in screeningdetected C282Y homozygous subjects. Scand J Gastroenterol 2007; 43: 782-3.

22. Haukeland JW, Lorgen T, Schreiner LT et al. Incidence rates and causes of cirrhosis in a Norwegian population. Scand J Gastroenterol 2007; 42: $1501-8$.

23. Swinkels DW, Jorna AT, Raymakers RA et al. Synopsis of the Dutch multidisciplinary guideline for the diagnosis and treatment of hereditary haemochromatosis. Netherl J Med 2007; 65: 452-5.

24. Beaton M, Guyader D, Deugnier Y et al. Noninvasive prediction of cirrhosis in $\mathrm{C} 282 \mathrm{Y}$-linked hemochromatosis. Hepatology 2002; 36: 673-8.

25. Morrison ED, Brandhagen DJ, Phatak PD et al. Serum ferritin level predicts advanced hepatic fibrosis among U.S. patients with phenotypic hemochromatosis. Ann Intern Med 2003; 138. 627-33.

26. Willis G, Bardsley V, Fellows IW et al. Hepatocellular carcinoma and the penetrance of HFE C282Y mutations: a cross sectional study. BMC Gastroenterol 2005: 5: 17.

27. Niederau C, Fisher R, Pürscehl A et al. Long-term survival in patients with hereditary hemochromatosis. Gatroenterology 1996; 110: 1107-19.

28. Brissot P. Diagnosis and current treatments for primary iron overload. Am J Hematol 2007; 82: 1140-1.

29. Norsk selskap for hematologi. Handlingsprogram for hemokromatose 2003. www.legeforeningen.no/ asset/22333/1/22333 1.doc (27.2.2009)

30. Adams PC, Barton JC. Haemochromatosis. Lancet 2007; 370: $1855-70$

31. Åsberg A. Arvelig hemokromatose - nytten av screening. Nor J Epidemiol 2006; 16: 23-8.

32. The U.S. Preventive Task Force. Screening of hemochromatosis: recommendation statement. Ann Intern Med 2006; 145: 204-8.

Manuskriptet ble mottatt 17.7. 2008 og godkjent 23.2. 2009. Medisinsk redaktør Trine B. Haugen. 